already been commenced by him on the taxonomy and biology of coprophilous and soil fungi, on the taxonomy, physiology and cytology of Helminthosporium species attacking cereals, and on abnormal growth in plants. B. Tiagi, appointed as reader, has a long record of active research in plant morphology and embryology. The Departmont will soon have a separate building together with a general herbarium of higher plants, a mycological horbarium and a collection of living cultures of fungi.

\section{Ford Foundation Research Fellowships of the Zoo- logical Society of London}

Iv May 1960 the Ford Foundation made a grant of 550,000 dollars to the Zoological Society of London to endow three senior research fellowships and three junior research fellowships in animal reproduction. The Council of the Society has now appointed Dr. Peter A. Jewell, Dr. Lorna M. Kollas and Mr. D. R. S Kirby to fellowships. Dr. Peter A. Jewell, who will hold the appointment for five years, is at present working at the Royal Veterinary Colloge on the breeding biology of Soay sheep, which are confined to the Island of St. Kilda, and which present unique material for the investigation of a population of small ungulates. He also intends to study the reproductive performance, under laboratory conditions, of various forms of Apodemus. Until suitable laboratory space is available at the Society's Gardens, Regent's Park, Dr. Jewell will work in the Department of Animal Husbandry and Veterinary Hygiene, Royal Veterinary College, London. Dr. L. M. Kellas, who is appointed for three years, at present holds an appointment in the Department of Veterinary Histology, University of Glasgow Veterinary School. Dr. Kellas will make a histological and histochemical study of the intra-epithelial granular cell which occurs in the placenta of ruminants. She will also study the reproductive tracts of the giraffe, having already obtained certain material for these studies while on field expeditions to Central Africa. $\mathrm{Mr}$. David R. S. Kirby has beon appointed for a period of three years, as from October 1, 1960, and for the time being will continue to work in the Department of Zoology and Comparative Anatomy in the University of Oxford. He will study the effects of abnormal environments on the development of the embryo, with particular reference to the inhibitory influence of the endometrium on the spread of the cells of the trophoblast.

\section{New Atomic Energy Authority Reactor}

A NEW low-power reactor called Vera (Versatile Experimental Reactor Assembly) started operating for the first time at the Atomic Weapons Research Establishment, Aldermaston, on February 22. It is being used in reactor physics experiments to improve nuclear data and methods of calculation for fast critical assemblies. More information on these systems is required for many problems relating to the safety of storage and processing of fissile materials, and for the fast reactor development programme. The reactor includes a core region of thin-walled steel fuel tubes surroundod by a natural uranium reflector - the whole forming a cylinder $4 \mathrm{ft}$. high and $5 \mathrm{ft}$. in diameter. The fuel tubes are loaded with fissile and diluent material plates 1.7 in. square and $\frac{1}{8}$ in. thick. By appropriate loadings the composition and size of the reactor core may be varied to examine the nuclear importance of materials over a wide range of neutron energios. The reactor is designed to separate into two parts for safo loading, the two halves being brought slowly together by remote control. An acelerator associated with Vera enables neutron bursts to be gonerated for measurements of reactivity and time-dependent bohaviour. The reactor is located in a large concrete cell which is sealed during operation. As the power will not exceed $100 \mathrm{~W}$. special cooling is not required. This work forms part of a programme of experimental and theoretical nuclear data work at the Atomic Weapons Research Establishment and is co-ordinated with fast reactor work in progress at other establishments of the U.K. Atomic Energy Authority.

\section{New British Base in the Antarctic}

A New British Antarctic base-one of the most southerly in the chain of scientific stations maintained by the Falkland Islands Dependencies Survey-has been set up on Adelaide Island. Sir Vivian Fuchs, director of the Survey, states that the new base is on the east side of Adelaide Island, in approximately latitude $67^{\circ} 40^{\prime} \mathrm{S}$. Adelaide Island is about 70 miles long and 30 miles wide with high mountains, the peaks of which reach 4,000-7,000 ft. The new base was established on February 3 and will enable the survey and geology of the Island to be completed, besides acting as a supply station from which men and stores can be flown to othor bases. Two Otter aircraft have already arrived at Adelaide and are at present in the course of flying stores to Fossil Bluff, the site of a new station in lat. $71^{\circ} 20^{\prime}$ S., long. $68^{\circ} 17^{\prime} \mathrm{W}$. This will be the farthest south base in the Graham Land area, and from it exploratory journeys will be made in Alexander Island, a high mountainous region some 20,000 square miles in extent.

\section{Afforestation in National Parks in Britain}

IN a written answer circulated in Hansard of February 14, the terms of a schems for afforestation in the national parks in Britain is given, together with a letter sent by the National Parks Commission on January 26, 1961, to the individual park planning authorities recommending its adoption. The purpose of the scheme is to secure consultation of the park planning authorities on proposals for private afforestation of any land that has not hitherto been planted. 'The Timber Growers' Organization, the Country Landowners' Association, the Forestry Commission and the National Parks Commission are all anxious to secure that in the future use of land in national parks, proper regard should be given both to the needs of forestry and to the preservation and enhance. ment of the natural beauty of the landscape. To avoid conflict between these two interests, the parties to the agreement believe that the closest co-operation should be maintained between those concerned with afforestation and those responsible for accomplishing the purposes for which national parks have been established, and they agree accordingly that the Park Planning Authorities should be given the opportunity of commenting on all proposals for the afforestation of any land not hitherto planted. In each national park, except where special arrangements have already been made, it is proposed that the Park Planning Authority should carry out with the Forestry Commission a survey with the view of compiling maps classifying the land in the park so far as possible into : (a) aress where there is a strong presumption 